Available Online at www.aextj.com

Agricultural Extension Journal 2018; 2(1):32-39

RESEARCH ARTICLE

\title{
Measurement of Technical Efficiency of Small Scale Farmers under the Growth Enhancement Scheme in Oyo State, Nigeria
}

\author{
I. O. Ogunwande, A. S. Ajila \\ Department of Agricultural and Resource Economics, The Federal University of Technology, Akure, Ondo State, \\ Nigeria
}

Received: 25-12-2017; Revised: 01-01-2018; Accepted: 20-01-2018

\begin{abstract}
The study investigated the technical efficiency of small-scale farmers under the growth enhancement scheme in Egbeda and Surulere Local Government Areas of Oyo State. Multistage sampling technique was used in the random selection of 250 respondents using copies of a structured questionnaire. The result of average input used of respondents was farm size (1.59ha), labor used (23 man-days), seed (30 kg), years of education (6.23 years), fertilizer (259.69 kg), and seasonal extension contact (7) while the average input per farm was $4,162.89 \mathrm{~kg}$. Efficiency of farmers was influenced by the significant input variables such as farm size (3.3749), fertilizer (0.2094), and experience were significant at $1 \%$ while years of education (0.6038) and agrochemicals (0.0846) were significant at $1 \%$ and $10 \%$, respectively. The distribution of efficiency score showed that farms within the range of $0.81-0.90$ were highest with $62.4 \%$. It was, therefore, recommended that policy that will stimulate more extension services and labor availability to improve on output.
\end{abstract}

Key words: Farmers, Frontier, Growth enhancement scheme strategy, Small scale, Technical efficiency

\section{INTRODUCTION}

The agricultural sector is central to Nigeria's economy and according to record accounts for about $40 \%$ of the country's gross domestic product (GDP) and provides $60 \%$ of employment. It is also a major source of raw materials for agro-based industries, and second to the oil sector in generating foreign exchange earnings for the economy. ${ }^{[9]}$ Between 2001 and 2007, the agricultural sector accounted for $51 \%$ of job creation in the country. In the 1960s, before the advent of the oil boom, Nigeria had over $60 \%$ of the global palm oil exports; $30 \%$ of global groundnut exports (in what used to be known as the groundnut pyramids); 20 $30 \%$ of global groundnut oil exports; and $15 \%$ of global cocoa exports. ${ }^{[2]}$

Since the 1970s, Nigeria had lost its dominant position in the export of key crops such as cocoa,

\section{Address for correspondence:}

I. O. Ogunwande,

E-mail: segunogunwande@gmail.com groundnuts, rubber, and palm oil ${ }^{[11]}$. By the year 2000, Nigeria's global share of exports of each of these major crops was $5 \%$ or less which reflects a high level of laxity and production deficiency. The advent of the oil boom in the early 1970s made the country highly dependent on oil revenue which eventually claimed the major part of the annual budget. Thus, instead of leveraging on the agricultural sector, the oil sector has depressed the sector to the extent that food insecurity and poverty have increased remarkably. ${ }^{[4]}$ Rural dwellers had been dependent on the agricultural sector, highly marginalized and pushed to the brink of desperation and total destitution resulting from insufficient government attention and commitment. Arising from this background, the agricultural sector has continued to make a very modest contribution to the economy's overall growth rate, and Nigeria's food security situation has continued to decline abysmally. ${ }^{[1]}$

Moreover, farm practice in Nigeria has for time immemorial known to be mostly managed by small farmers who are resource-poor and, practice with 
a crude implement and lack of enough institutes and policies as managing tools in the agricultural sector which evidently leads to low efficiency and in turn, low income. ${ }^{[7]}$ Against this background, many institutes and policies were created in order create more awareness, provide guidance and finance their farm practices. New policies and regulations that can spur investment seem to be the missing link needed to transform the country's abundant resources into a sector focused on food production and poverty reduction, particularly among smallholder farmers. ${ }^{[10]}$ Some of the policies and programs put in place by government in the post-independence era were national accelerated food production programme, national economic empowerment development strategy, directorate for food road and rural development, national accelerated land development authority among others which although were affected by paucity of funds and administrative lapses. ${ }^{[7]}$ Most recently was the introduction and implementation of the agricultural transformation Agenda (ATA) with a specific target on the growth enhancement scheme strategy (GESS). ${ }^{[14]}$

To unlock the potential of its agricultural sector, Nigeria embarked on a major transformation with the launch of the ATA in July 2012. The goals are to add 20 million metric tons of food to the domestic food supply by 2015 and to create 3.5 million jobs. ${ }^{[18]}$ The Agenda's focus is on driving import substitution by accelerating the production of local staples, to reduce dependence on food imports and turn Nigeria into a net exporter of food. ${ }^{[3]}$ To reduce food import spending and harness Nigeria's agricultural potential, as well as create jobs in the agricultural and agribusiness sector, the country embarked on an ATA to reposition agriculture to drive Nigeria's economy, building on the foundation established through the African Union's Comprehensive Africa Agriculture Development Programme process. ${ }^{[9]}$ Nigeria's reliance on food imports is due in part to underperformance in the agricultural sector, with yield per hectare $20-50 \%$ of that produced in similar developing countries up to 2009. ${ }^{[2]}$ A driving factor of low yields was attributed to very low usage rates of agricultural inputs and increasing the use of improved seeds and fertilizer was seen as essential to the success of the broader ATA program. ${ }^{[18]}$ Nigeria has been implementing large-scale fertilizer subsidies since the 1970s, and fertilizer supply has been the single largest expenditure item in the federal capital account. Despite the considerable fiscal burden to the government, actual use of fertilizer by farmers was very low. The subsidy policy was widely recognized as being associated with multiple problems, including wide-scale corruption and inefficiencies. Over 776 billion naira ( $\$ 4.8$ billion) was estimated to have been lost to corruption in total, averaging 26 billion naira ( $\$ 162.5$ million) of losses annually. ${ }^{[6,9]}$ A key feature of Nigeria's old system of fertilizer subsidy was a very active role of the state in fertilizer delivery.

However, growth enhancement support (GES) program was launched in 2012, with the primary objective to depoliticize the input sector by withdrawing the state from procurement of inputs and developing a private sector channel for input distribution. ${ }^{[5]}$ This giant stride taken by the federal government particularly led to total removal of subsidy which encouraged the fertilizer dealers in the country to hoard and sell at a future date to farmers at exorbitant prices. Therefore, government sold fertilizer at the current market price and introduced the policy of buy one and get an additional one. Furthermore, other inputs such as seedlings and seeds and hitch-free extension services were given to farmers who were duly registered under the accredited dealer for free. ${ }^{[8]}$

Against the backdrop of the effort of the government in the improvement of agricultural production for all scales of farming, inputs were made available and accessible while credits and loans were also made available. However, with all these supports in place, farm output in both crop and livestock aspects is at its lowest level while population increases by the day and food shortage assume a greater dimension. ${ }^{[1]}$ For agricultural production to be appreciable and available in good quantity to support the ever-increasing Nigerian population, efficiency in farm production must be given thorough attention. The study hopes to answer the following research questions; what are the socioeconomic characteristics of small-scale farmers under the GES? What factors determine the efficiency of farms? What is the individual farm efficiency of farmers? These and other germane questions are to be provided lucid and relevant answers for policy purpose. The objectives of the study are to identify the socioeconomic characteristics of respondents; analyze the factors that determine the efficiency of small-scale farms and examine the individual farm efficiency. 


\section{Agricultural production in Nigeria}

\section{Research methodology}

The study area

The study was carried out in Egbeda and Surulere local government areas (LGAs) of Oyo State. The former is situated in the Guinea Savanna zone while the latter is located in the rainforest vegetation belt. Egbeda LGA is bounded in the North by Lagelu LGA and in the South by Ona-Ara LGA; to the West by Ibadan North East while in the East bounded by Osun State. It has a population of $319,388,{ }^{[16]}$ and land is of $410 \mathrm{~km}^{2}$. It is popularly identified with weather elements that favor agricultural practices which are evident in moderately weathered soil that permits the cultivation of both deep-rooted and surface feeder crops. The mean annual temperature and rainfall in the LGA are $1650 \mathrm{~mm}$ and $\pm 26.5^{\circ} \mathrm{C}$, respectively, and its sunshine is relatively optimal. The LGA is agrarian, and the main occupation of the inhabitant is farming. ${ }^{[17]}$

Surulere LGA is bounded in the North by Ogbomoso LGA and to the South by Ogo Oluwa LGA. It is bounded to the West by Ogbomoso South and in the East by Ogo Oluwa LGA. It has a population of 126,692 and a land area of $975 \mathrm{~km}^{2}$. The mean annual temperature and rainfall in the area are $\pm 27^{\circ} \mathrm{C}$ and $2550 \mathrm{~mm}$, respectively. Its edaphic quality revealed that the soil is moderately weathered which prompt the retention of nutrients for both the surface feeder and the deep-rooted crops. ${ }^{[17]}$ Sunshine intensity is optimal for the existence and sustenance of both the biotic and abiotic organisms.

Both Egbeda and Surulere LGAs share a lot of common ecological/agro-climatic conditions, and the socioeconomic characteristics of the inhabitants in the LGAs are similar. The dominant tribe in the two LGAs is Yoruba, while another ethnic group such as Hausa, Igbo, Egede, Agatu, Tiv, Nigerien, and Malian peacefully cohabit with their host in the areas and engage in both agricultural and nonagricultural activities. The two LGAs host the Agricultural Development Project staff and this paves the way for farmers in the area to access innovation through the visit of extension agents for both advisory and field demonstration purposes. Furthermore, farmers' unions are present and active in the areas in question.

\section{Type of data and instrument of data collection}

For the purpose of achieving the objectives of this study, primary data were extensively explored on socioeconomic variables (age, gender, household size, marital status level of education, and primary occupation) and input variables (farm size, seed, fertilizer, herbicide, and labor). The instruments used for the data collected were copies of a structured questionnaire, voice recorder (e.g., handset and tape recorder), and interview schedule.

\section{Sampling technique}

Multistage sampling technique was used to obtain representative sample unit used in the study. The first stage was the purposive selection of two LGAs, Egbeda and Surulere, from the 33 LGAs in the state. Five communities were purposively selected from each of Egbeda and Surulere LGAs giving a total of 10 . Given the total of the two LGAs as about 447,000; Egbeda LGA is about 72\% (about 320,000) while Surulere LGA has about 28\% (about 127,000); from which 10 respondents randomly were randomly selected from each community in Surulere and 15 respondents also randomly selected from Egbeda LGA giving a total of 100 from Surulere and 150 from Egbeda forming a total of 250 respondents reached, selected and interviewed for the study. Table 1 shows the detail of sampling procedure.

\section{Analytical tool}

Both simple statistical and parametric tools were used in the analysis of data in the study. The simple statistical tool used was descriptive such as mean, maximum, and minimum while the parametric tool used was the stochastic frontier production Function (SFPF). The tool was used based on its

Table 1: Sampling procedure details

\begin{tabular}{llc}
\hline LGA & Community & No. Respondents \\
\hline Egbeda & Egbeda & 10 \\
& Erunmu & 10 \\
& Gbopa & 10 \\
& Olode & 10 \\
& Osegere & 10 \\
Surulere & Okin & 15 \\
& Gambari & 15 \\
& Iresa Adu & 15 \\
& Oko & 15 \\
& Iresa Apa & 15 \\
Total & & 250 \\
\hline
\end{tabular}

Source: Field Survey, 2017. LGA: Local government area 
unique strength of separating errors which affect farm level production from the effects of input and socioeconomic variables on farm output.

\section{The stochastic frontier production function}

Adesina $^{[12]}$ and Ajibefun ${ }^{[15]}$ independently proposed the stochastic frontier production function model of the form

$\ln \mathrm{q}=\mathrm{x}_{\mathrm{i}}^{\prime} \beta+\mathrm{v}_{\mathrm{i}}-\mathrm{u}_{\mathrm{i}}$

Equation 1 could otherwise be expressed as:

$\ln \mathrm{q}=\mathrm{x}_{\mathrm{i}}^{\prime} \beta-\mathrm{u}_{\mathrm{i}} \mathrm{i}=1 ., 1$.

Where, $\ln$ is natural logarithm, q represents quantity of output, $\mathrm{x}_{\mathrm{s}}$ denote vector of explanatory variables; $\beta_{\mathrm{s}}$ are vector of parameters to be estimated; $\mathrm{u}_{\mathrm{s}}$ and $\mathrm{v}_{\mathrm{s}}$ are inefficiency parameters and random errors, respectively.

The difference in the two equations is the presence of $v_{i}$ in Equation 1 which is the symmetric random error that accounts for statistical noise which arises from the inadvertent omission of relevant variables from the vector $\mathrm{x}_{\mathrm{i}}$, as well as from measurement errors and approximation errors associated with the choice of functional forms.

The model 1 defined is stochastic frontier production function because, the output values are bounded by the stochastic (i.e., random) variable $\exp \left(\mathrm{x}_{\mathrm{i}}^{\prime} \beta+\mathrm{v}_{\mathrm{i}}\right)$.

Cobb Douglas stochastic frontier model used takes the form:

$\ln \mathrm{q}=\beta_{0}+\beta_{1} \operatorname{Inx}_{\mathrm{i}}+\mathrm{v}_{\mathrm{i}}-\mathrm{u}_{\mathrm{i}}$

and the technical efficiency of ith farmers is expressed as:

$$
\begin{aligned}
& \mathrm{TE}_{\mathrm{i}}=\frac{\mathrm{qi}}{\exp \left(\mathrm{x}^{\prime} \mathrm{i} \beta+\mathrm{vi}\right)}=\frac{\exp \cdot\left(\mathrm{x}^{\prime} \mathrm{i} \beta+\mathrm{vi}-\mathrm{ui}\right)}{\exp \cdot\left(\mathrm{x}^{\prime} \mathrm{i} \beta+\mathrm{vi}\right)}= \\
& \exp \cdot\left(-\mathrm{u}_{\mathrm{i}}\right)
\end{aligned}
$$

The measure of technical efficiency takes a value between 0 and 1 . It measures the output of the i-th firm relative to the output that could be produced by a fully efficient firm using the same input vector. Clearly, the first step in predicting the technical efficiency, TE, is to estimate the parameters of the stochastic production frontier model in Equation 2.

\section{Model specification}

Stochastic frontier production function used in this study follows the selection of variables in line with $^{[13]}$ as:

$\ln \mathrm{Q}=\beta_{0}+\beta_{1} \ln \mathrm{X}_{1}+\beta_{2} \mathrm{X}_{2}+\ldots+\beta_{\mathrm{n}} \mathrm{X}_{\mathrm{n}}+\mathrm{e}_{\mathrm{i}}$

\section{Input variables}

$\beta_{0}-\beta \mathrm{n}=$ Vectors of estimated parameters

$\mathrm{Q}=$ Quantity of output (in $\mathrm{kg}$ )

$\mathrm{X}_{1}=$ Farm size (in $\mathrm{Ha}$ )

$\mathrm{X}_{2}=$ Labor (in man-days)

$\mathrm{X}_{3}=$ Seed (in $\mathrm{kg}$ )

$\mathrm{X}_{4}=$ Fertilizer $($ in $\mathrm{kg})$

$\mathrm{X}_{5}=$ Agrochemicals (in liters)

NB: Q is Arable crops converted to maize grain equivalent weight

While the in-efficiency equation is given as:

$\mathrm{U}=\delta_{0}+\delta_{1} \mathrm{z}_{1}+\delta_{2} \mathrm{z}_{2}+\delta_{2} \mathrm{z}_{2}+\delta_{2} \mathrm{z}_{2}+\delta_{5} \mathrm{z}_{5}$

$\delta_{0}-\delta_{5}=$ vectors of inefficiency parameters to be estimated:

$\mathrm{z}_{1}=$ Age (in years)

$z_{2}=$ Education (in years)

$\mathrm{z}_{3}=$ Experience (in years)

$\mathrm{z}_{4}=$ Extension contacts (Nos.)

$\mathrm{z}_{5}=$ Gender $($ male $=1$; female $=0)$

N.B.: Small-scale farms size ( $\leq 2$ ha) used in this study is according to Adubi and Daramola (1996).

\section{RESULTS AND DISCUSSION}

\section{Level of input consumption and socioeconomic characteristics of respondents}

Socioeconomic characteristics, level of input consumption of respondents is presented in Table 2. Mean farm output of respondents was $4,162.89 \mathrm{~kg} / \mathrm{ha}$ and the maximum was $96,791.65 \mathrm{~kg} /$ ha. This result shows that respondents attained over $200 \%$ increase in output per hectare from previous 1.85 tonnes per hectares. It could be inferred that farmers under the GES may likely be efficient in the particular production season under examination.

Farm size under the GES recorded a significant boot as mean hectare cultivated was 1.59 ha, and the maximum was 10.10 ha This result shows that there was an improvement in area expansion for the cultivation of arable crop under the scheme from 0.65 ha previously cultivated in the study area (source). Improvements in yield as reported above cum area expansion suggest that farmers under the GES program may have achieved a higher level of productivity. Furthermore, availability of more land to farmers indicates their readiness to embrace program/project they perceived has capacity to better their economic activities.

The mean and maximum labor used in man-days by the respondents in the study area was 65 and 93 accordingly. This result reveals that participants in 
Table 2: Socioeconomic and input characteristics of respondents

\begin{tabular}{lccc}
\hline Variable & Mean & Maximum & Minimum \\
\hline Total Output (in Kg/Ha) & $4,162.89$ & $96,791.65$ & - \\
Farm-size (in hectares) & 1.59 & 10.10 & - \\
Labor (in man-days) & 23 & 65 & - \\
Seed (in kg) & 30.79 & 140 & - \\
Fertilizer (in kg) & 259.69 & 1300 & - \\
Agrochemicals (in litres) & 3.85 & 26 & - \\
Farmers' age (in years) & 48.5 & 75 & - \\
Education (in years) & 6.23 & 13 & - \\
Farmers' experience (in years) & 23.74 & 67 & - \\
Extension contacts (No.) & 7 & 24 & - \\
Sample Size (n)-250 & - & - & - \\
\hline
\end{tabular}

Source: Field Survey, 2015

GES used less man-day in their farm operation. Information gathered from the key informants in the selected communities revealed that farmers under the scheme substituted agrochemicals, especially herbicide for labor in their weeding operation, which requires 15 man-day per hectare, against three man-day when herbicide is used. More importantly, GES farmers' preference for agrochemicals was predicated on its costeffectiveness and efficiency in weed control. The use of agrochemicals by GES farmers shows that average consumption was $3.85 \mathrm{~L} /$ ha and maximum dosage applied was $26 \mathrm{~L}$. The results indicate that there is underutilization of agrochemical (herbicide), considering the standard application rate $(5 \mathrm{~L} / \mathrm{ha})$ of herbicide by the respondent, as well as mean and maximum hectare cultivated by the maize farmers in the study area. With respect to the seed planted by farmers under the scheme, mean seed cultivated per hectare was $30.79 \mathrm{~kg}$ and the maximum $140 \mathrm{~kg}$; depending on farm size; meaning that GES farmers had access to improved planting materials. The use of fertilizer by GES farmers in the study area was significant as respondents applied $259.69 \mathrm{~kg}$ (on the average) per hectare while the maximum quantity used was $1300 \mathrm{~kg}$. These results imply that input distribution model of the scheme benefitted most of the participants in terms of access and affordability. However, it might be necessary to properly train some of the farmers on the appropriate application rate to enhance their efficiency.

The socioeconomic characteristics of respondents with respect to age, level of education farming experience, extension contact, and gender are presented in Table 1. The dominant age of respondents which coincide with the mean age was 49 years, while minimum and maximum ages were 20 years and 75 years, respectively. The dominant age class revealed that the majority (72\%) of the respondent are economically vibrant to perform optimally in terms of labor-use in their farm operations. Educational levels of GES farmers in the study area show that the majority $(65 \%)$ spent over 12 years on schooling and the mean was 6 years. This result shows that the farmers under the scheme were literate and have capacity to access, process and utilize information appropriately to improve their socioeconomic well-being.

The year of farming experience of respondent shows that majority (68\%) of GES farmers in the study area had 20 years farming experience with a maximum of 25 years and mean value of 13 years. The level of experience acquired over the years may have assisted them in the area of optimal input combination, input price allocation among others which inadvertently enhanced high productivity. Furthermore, a number of extension contacts range from 7 to 24 per annum. The number of extension visit in a season was adjudged inadequate to achieve better output.

\section{Maximum likelihood estimate (MLE) of respondents' technical efficiency}

Table 3 shows the MLE of the determinants of technical efficiency of GES farmer. Among the efficiency variable; farm size, quantity of fertilizer and quantity of agrochemicals were positive and significant at various conventional levels of $1 \%$, $5 \%$, and $10 \%$, respectively. The results imply that as farm size increases, farm output increases and 
Table 3: MLE of the technical efficiency of GES farmers

\begin{tabular}{|c|c|c|c|}
\hline Input variables & Coefficient & Standard error & T-ratio \\
\hline \multicolumn{4}{|l|}{ Efficiency variable } \\
\hline Constant $\beta 0$ & $3.3749 * * *$ & 0.5359 & 6.3 \\
\hline Farm size (in $\mathrm{Ha}$ ) $\beta 1$ & $0.1204 * *$ & 0.0434 & 2.8 \\
\hline Labor (in mandays) $\beta 2$ & -0.0060 & 0.1250 & 0.1 \\
\hline Seed (in kg) $\beta 3$ & -0.0165 & 0.1220 & 0.2 \\
\hline Fertilize (in kg) $\beta 4$ & $0.2094 * * *$ & 0.0419 & 4.5 \\
\hline Agrochem (in liters) $\beta 5$ & $0.0487^{*}$ & 0.0200 & 2.4 \\
\hline \multicolumn{4}{|l|}{ Inefficiency variable } \\
\hline Constant $\delta 0$ & -0.2979 & 0.4820 & -0.6 \\
\hline Age (in years) $\delta 1$ & 0.0370 & 0.0415 & 0.89 \\
\hline Education (in years) $\delta 2$ & $-0.6038^{* *}$ & 0.1981 & -3.1 \\
\hline Experience (in years) $\delta 3$ & $-0.0846^{* * *}$ & 0.0160 & -5.3 \\
\hline Extension contacts (No.) $\delta 4$ & 0.2005 & 0.1416 & 1.4 \\
\hline Household size (No.) $\delta 5$ & 0.4489 & 0.4728 & 0.9 \\
\hline Gender $\delta 6$ & -0.1753 & 0.4712 & -0.37 \\
\hline \multicolumn{4}{|l|}{ Diagnosis statistics } \\
\hline Sigma $\sigma$ & $0.96^{* * *}$ & 0.3825 & 24.9 \\
\hline Gamma $\Upsilon$ & $0.92 * * *(0.08)$ & 0.0297 & 31.12 \\
\hline L g-likelihood function & -87.94 & & \\
\hline Likelihood ratio & 28.56 & & \\
\hline Sample size (n) & 250 & & \\
\hline Mean Tech. Eff. & $0.72(72 \%)$ & & \\
\hline
\end{tabular}

MLE: Maximum likelihood estimate, GES: Growth enhancement scheme

significant at 5\% level. A unit increase in farm size on the average leads to $0.1204 \%$ increase in farm output. Furthermore, the quantity of fertilizer used was found to be significant at $1 \%$. A unit increase in fertilizer applied on the average leads to 0.2094 unit increase in the quantity output. Agrochemical was also found to have a direct relationship with farm output and was significant at $10 \%$. A unit increase in the quantity of agrochemicals used on the average leads to 4 units increase the quantity of output.

The inefficiency model reveals that age, education, experience, and gender of respondents were found to have signs of interest and were also significantly different from zero at the levels of $1 \%, 5 \%$, and $10 \%$, respectively. As shown in Table 2, number of years of schooling was significant at $5 \%$ and positively related to output. A unit increase in the years of education leads on the average to 6 units increase in farm output. It could be inferred from this result that, farmers with more years of education would be more technically efficient. Years of experience of farmers positively influenced farm output and found to be significantly at $1 \%$. A unit increase in years of experience leads on the average to 8 unit increase in farm output. This result suggests that years of farming experience has a positive correlation with output accrued to individual farmer. Gender (male) of respondents has a positive relationship with farm output and was found to be significant at $5 \%$. A unit increase in the number of male farmers leads on the average to 0.1753 unit increase in farm output. It could be inferred from this result that men are stronger and this quality enables them to cope with an extremely energy demanding farm chores which their female counterparts may find extremely difficult to cope with.

\section{Elasticity/return to scale (RTS) of the Cob- Douglas SPF function}

Details of average elasticity of input used by the respondents are presented in Table 4. The overall elasticity value of various inputs combined by farmers under GES scheme was $<1(0.81)$. This explains that they are operating at decreasing return to scale which is the stage II of the production frontier under which any rational farmers should operate. However, the gap between the actual and potential efficiency frontier could be filled with about 0.19 efficiency rate. It could, therefore, be deduced that the optimal combination of available 
Table 4: Elasticity/return to scale (RTS) of the Cob-Douglas SFP function

\begin{tabular}{lc}
\hline Variable & Elasticity/RTS \\
\hline Farm size & 0.12 \\
Labor (in man-days) & -0.21 \\
Seed (in kg) & -0.18 \\
Fertilizer (in kg) & 0.21 \\
Agrochemicals (in liters) & 0.09 \\
Total & 0.81 \\
\hline
\end{tabular}

Source: Field Survey, 2016. SFP: Stochastic frontier production

Table 5: Distribution of technical efficiency scores of farmers under GES scheme

\begin{tabular}{lc}
\hline Technical efficiency score & Frequency (\%) \\
\hline$\leq 0.10$ & - \\
$0.11-0.20$ & $01(0.40)$ \\
$0.21-0.30$ & - \\
$0.31-0.40$ & $02(0.80)$ \\
$0.41-0.50$ & $01(0.40)$ \\
$0.51-0.60$ & $08(3.20)$ \\
$0.61-0.70$ & $15(6.00)$ \\
$0.71-0.80$ & $49(19.60)$ \\
$0.81-0.90$ & $156(62.40)$ \\
$>0.91$ & $18(7.20)$ \\
Total & $250(100.00)$ \\
\hline
\end{tabular}

Source: Field Survey, 2016. GES: Growth enhancement scheme

input necessary to achieve optimum efficiency level could be attained.

\section{Distribution of technical efficiency scores of farmers under GES scheme}

Frequency distribution of individual farm efficiency of maize farmers under the scheme in the study area is presented in Table 4. Information contained in the Table 5 revealed that most $(82 \%)$ of the farmers operated at efficiency range of $0.71-0.90$, while the highest $(62.4 \%)$ and lowest $(0.40 \%)$ were recorded for farm performance in the production possibility range. The result showed that majority of the farmers operated at the high decile of the efficiency range suggesting that, farm output under GESS in the study area was good in the season under consideration. The Technical Efficiency Score Distribution of farmers under GES Scheme is also revealed in Figure 1 below.

\section{CONCLUSION AND RECOMMENDATIONS}

Maize farmers' technical transformation of input into output in the study area was found to be

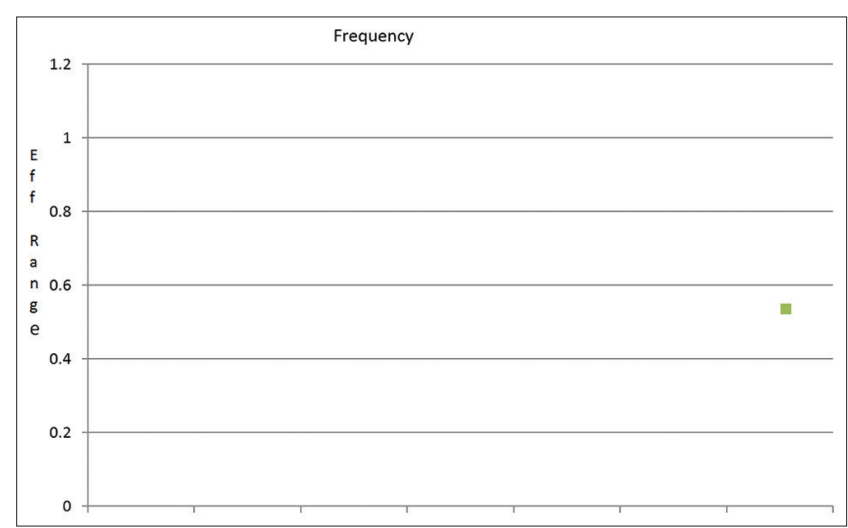

Figure 1: Technical efficiency score distribution of farmers under growth enhancement scheme scheme. Source: Field Survey, 2017

efficient as the rate of technical substitution (RTS) was $81 \%$. Majority $(62.4 \%)$ of farmers operated within the efficiency score of between 0.81 and 0.90 while the mean efficiency score for all farmers under the transformation program was $72 \%$, suggesting that the farmers understudy still have an ample efficiency range of $28 \%$ to operate to attain the maximum frontier on the production possibility surface. Furthermore, all farmers operated at stage II of the production range. This implies that optimum efficiency (enhanced productivity) rather than area expansion is a viable option to stem up level of production of arable crop in the study area. Based on the findings, it is recommended that:

i. Effective and efficient extension services through well-trained and seasoned extension agents must be provided to transfer adequate knowledge/skill on application rates of specific agro-chemical and proper time of its application to achieve desired production target.

ii. Appropriate planting materials and technologies are developed and extended to farmers at the right time and affordable prices.

iii. Innovative input distribution model should be developed to ensure farmers have unhindered access.

\section{REFERENCES}

1. Adesina A. Honorable Minister of Agriculture and Rural Development, Federal Republic of Nigeria, Governor from Nigeria, at the $36^{\text {th }}$ Session of the IFAD Governing Council; 2013.

2. Adubi AA, Daramola AG. An empirical analysis of risk and expected return on small scale agriculture in Nigeria. Q J Int Agric 1996;35:384-97. 
3. Akinboro B. Bringing mobile wallets to Nigerian farmers. In: Financial Innovation for Smallholder Families. Pakistan: Digital Financial Services; 2014. p. 3.

4. Akinyosoye VO. Plant size and factor productivity in agro-allied industries: Implications for Nigeria's new industrial policy. J Rural Econ Dev 2006.

5. Fertilizer Subsidy Reform. Fertilizer Subsidy Reform Revives Nigeria's Agriculture Grow Africa; 2014. Available from: https://www.growafrica.com/sites/ default/files/fertilizer-subsidy-reform-web.pdf. [Last accessed on $2017 \mathrm{Jul} 21$ ].

6. Henry-Ukota AC, Osuji MN, Ukoha II. Rate of information communication technologies (ICTs) use: Its determinants among livestock farmers in UkwaWest LGA, Abia State, Nigeria. Int J Agric Food Sci 2012;2:51-4.

7. Idachaba F. Food Security in Nigeria: Challenges Under Democratic Dispensation. Paper Presented at Agricultural and Rural Management Training Institute (ARMTI). Ilorin: ARMTI Lecture; 2004. p. 1-23.

8. IFPRI/IFDC. Census of Agricultural Input Dealers in Ghana. Washington DC: International Food and Policy Research Institute and International Fertilizer Development Center Survey; 2009.

9. Nwalieji HU, Uzuegbunam CO, Okeke MN. Assessment of growth enhancement support scheme among rice farmers in Anambra State, Nigeria. J Agric
Ext 2015;19:71-81.

10. Ojoko E. Growth enhancement support scheme (GESS) and the challenges of food security in Nigeria: A review. J Agric Biol Sci 2014;9:226-32.

11. Okunseinde M. The Electronic Wallet System: How Nigeria is Dialing into its Agricultural Sector. Washington DC: Covington and Burling LLP; 2014.

12. Adesina A. Presidential Brief Agricultural Transformation Agenda. Abuja: Presentation Made by the Honorable Minister of Agriculture to the Economic Management; 2011.

13. Aigner DL, Lovell CA, Schmidt P. Formulation and estimation of stochastic frontier models. J Econ 1977;6:21-37.

14. Ajibefun IA, Daramola AG. Measurement and sources of technical in-efficiency in poultry egg production. J Rural Econ Dev 1998;13:1-3.

15. Ajibefun IA. An investigation of technical in-efficiency of production of farmers under the directorate of employment in Ondo State, Nigeria. J Appl Trop Agric 1998;3:15-21.

16. Meeusen W, Van den Broeck J. Efficiency estimation from cobb Douglas production functions with composed error. Int Econ Rev 1977;18:435-44.

17. NPC. National Population Commission Statistical Book. Beijing: China Statistics Press; 2006.

18. Oyo State Diary. The State Diary of Oyo State, Oyo State, Nigeria; 2010. 